\title{
Effects of 2,4-DP- P (2,4-Dichlorophenoxypropionic Acid-P) Plant Growth Regulator on Fruit Size and Yield of Star Ruby Grapefruit (Citrus paradisi Osb.)
}

\author{
Bilge Yılmaz ${ }^{1}$, Berken Cimen ${ }^{1 *}$, Turgut Yesiloglu ${ }^{1}$, Meral Incesu ${ }^{1}$, Muge Uysal Kamiloglu ${ }^{2}$, \\ Muharrem Yilmaz
}

${ }^{1}$ Department of Horticulture, Agriculture Faculty, Çukurova University, 01330 Adana, Turkey

${ }^{2}$ Department of Horticulture, Agriculture Faculty, Mustafa Kemal University, 31060 Antakya/Hatay, Turkey

${ }^{3}$ Department of Horticulture, Faculty of Agriculture, Ordu University, 52200 Ordu, Turkey

A R T I C LE INFO

\section{Research Article}

Received 13 June 2018

Accepted 06 August 2018

\section{Keywords:}

Auxin

Fruit quality

Star Ruby grapefruit

Yield

Plant growth regulators

*Corresponding Author:

E-mail: bcimen@cu.edu.tr

\begin{abstract}
A B S T R A C T
Star Ruby is the main grapefruit (Citrus paradisi) variety grown in Turkey; however, small fruit size is a common problem in 'Star Ruby' grapefruit. Fruit size is a decisive external quality parameter in citrus at the marketing of fresh citrus fruits. Fruit size can be enhanced by several techniques such as girdling and thinning. Various plant growth regulators are known to affect the growth and size of citrus fruit. The objective of the present study was to observe the effects of 2,4 dichlorophenoxypropionic acid-p (2,4-DP$\mathrm{P}$ ) on the fruit size, yield and quality of Star Ruby from 20-year-old trees budded on sour orange rootstock in Adana, Turkey in 2007. Four concentrations (50, 100, 150 and 300 ppm) of 2,4-DP-P were applied 8 weeks after anthesis during physiological fruit drop when the mean fruit diameter was $13-15 \mathrm{~mm}$. The results indicated that the application of 2,4-DP-P increased the fruit size of Star Ruby grapefruit without reducing yield. The application had a significant effect on fruit yield except for trees treated with $50 \mathrm{ppm} 2,4$ DP-P. Compared with the control trees, applications of 2,4-DP-P increased the number of large, commercially valuable Star Ruby (>93 mm, 89-93 mm and $84-89 \mathrm{~mm}$ ). No effects were determined on fruit internal quality parameters. Thus, the results of the present study revealed that 2,4-DP-P can be used to improve the fruit size of Star Ruby fruitlets during the June drop.
\end{abstract}

DOI: https://doi.org/10.24925/turjaf.v6i9.1279-1284.2065

\section{Introduction}

Citrus growing areas of Turkey are situated in the northern hemisphere of the citrus belt and Turkey has very suitable ecological conditions and potential for citrus production where 4.293.007 $\mathrm{t}$ of citrus fruit were produced in 2016 (TUIK, 2017). The east Mediterranean Region pro-duces $80 \%$ of Turkey's total citrus fruit and $99 \%$ of the grapefruit. For instance, Turkey produced $253.120 \mathrm{t}$ of grapefruit in 2016 (TUIK, 2017) and exported $183.329 \mathrm{t}$ of this production quantity in the same year (AKIB, 2017). The main grapefruit (Citrus paradisi) variety grown in Turkey is the 'Star Ruby' cultivar. In recent years, there has been a large increase in the exportation of citrus fruits, especially grapefruit. The planting of the 'Star Ruby' grapefruit has been extended in regions of Turkey that are already developed in terms of citriculture. The 'Star Ruby' grapefruit is desirable due to characteristics such as seed lessness, shape, smooth rind, colour and taste. However, small fruit size is a common problem in 'Star Ruby' grapefruit, especially in the older trees of Star Ruby. Moreover, small fruit size is the main factors limiting the sales of Star Ruby grapefruit; thus, large fruit brings higher prices in the export market (Yildırım et al., 2010; 2012).

Consumers prefer large fruits; thus, there is a significant price difference between large and small fruits (Agusti et al., 1994; Guardiola and Garcia Luis 2000; Erner et al., 2004). In terms of determining profitability, fruit size in citrus fruit has become as important as the yield. This phenomenon is readily apparent for small mandarin fruits, as well as lemons, sweet oranges and large grapefruit species (Guardiola and Garcia Luis, 2000). Fruit size is affected by many factors including irrigation management, soil type, rootstock and ecological variables, which can-not be controlled by the producer. 
Moreover, fruit size is inversely proportional to yield and fruit number (Guardiola 1997). The availability of carbohydrates (increases fruit size), flower intensity (decreases fruit size), competition between flowers/fruitlets (decreases fruit size) and abiotic stresses (decrease fruit size) are the most important factors affecting the final fruit size of citrus fruits (Agusti et al., 1995; Goldschmidt and Koch et al., 1996; El-Otmani et al., 2000)

Synthetic auxins can be applied to increase fruit size (Wheaton, 1981; Gallasch, 1988) Applying synthetic auxins during the cell division stage of fruit development significantly reduces the number of fruits and increases the final fruit size by reducing the competition for carbohydrates between fruitlets (Agusti et al., 1995). Synthetic auxins such as 2,4-dichlorophenoxyacetic acid (2,4-D), 2,4,5-trichlorophenoxy acetic acid (2,4,5-T), naphthalene acetic acid (NAA) and 2,4 dichlorophenoxypropionic acid (2,4-DP) have been shown to increase fruit size (Guardiola et al., 1988; ElOtmani et al., 1993; Agusti et al., 1994). Studies made by Laskowski et al. (2008) demonstrated a strong correlation of higher endogenous Indole acetic acid (IAA) content with the growth rate in the Salustiana orange during early fruit development.

In this study, the effects of 2,4-DP-P on fruit size and yield of Star Ruby grapefruit cultivar was investigated.

\section{Materials and Methods}

\section{Trees and Treatments}

The experiments were conducted on 20-year-old Star Ruby grapefruit trees planted on sour orange rootstock at $8 \mathrm{~m} \times 8 \mathrm{~m}$ intervals at the Research Station of Çukurova University, Agricultural Faculty Citrus Experiment Station, Adana (latitude, $35^{\circ} 23^{\prime} \mathrm{N}$; longitude, $36^{\circ} 50^{\prime} \mathrm{E}$; altitude $27 \mathrm{~m}$ ) in 2007 . The trees were managed and selected for uniformity and crop load. In the experimental area, the soil was a clay loam (55\% clay, $22 \%$ silt and $23 \%$ sand containing $11 \% \mathrm{CaCO}_{3}$ ), and the soil $\mathrm{pH}$ was between 7.20 and 7.29 at a depth of $0-90 \mathrm{~cm}$. The trial was organized in a randomized complete block design with nine replicates for each treatment. The trees were pruned regularly and irrigated weekly from May to October. Pest populations were controlled with a recommended pest management program. 2,4-DP-P (25 g of dichlorophenoxypropionic acid-p per L) was applied to the entire tree at concentrations of 50, 100, 150 and 300 ppm. At the time of application, the diameters of 125 randomly selected fruitlets were measured. Treatments were performed 8 weeks after anthesis during physiological fruit drop, when the mean fruit diameter was $13-15 \mathrm{~mm}$. Treatments were applied with a highpressure handgun sprayer to the entire tree, and each tree received $10 \mathrm{~L}$ of the 2,4-DP-P solution, depending on the size of the tree.

\section{Fruit Yield and Size}

The fruit was harvested in 2007 at the optimal harvest time (in December). The yield per tree ( $\mathrm{kg} /$ tree) was obtained by weighing the harvested fruit. Tree height and canopy diameter in the two tree directions (to obtain the average diameter) were measured after harvesting.
Canopy volume (CV) was calculated according to the equation reported by Turrell (1946) as follow: CV = $0.5248 \times$ canopy height $\mathrm{x}$ canopy diameter. In addition, scion trunk circumferences were measured $10 \mathrm{~cm}$ above the bud union. The scion trunk circumferences were converted into trunk cross-sectional area (TCSA). Yield efficiency was estimated as the ratio of fruit yield to canopy volume $\left(\mathrm{kg} / \mathrm{m}^{3}\right)$ and trunk cross sectional unit area $\left(\mathrm{kg} / \mathrm{cm}^{2}\right)$. A random sample of 25 fruits from each tree was collected to analyse for fruit quality. In addition, fruits from each of the plots were weighed to determine the average fruit size. The fruit was sized at the equatorial diameter and graded according to the following commercial size classes: $>93 \mathrm{~mm}$ (class 1), 89 - $93 \mathrm{~mm}$ (class 2), 84 - $89 \mathrm{~mm}$ (class 3), 80 - $84 \mathrm{~mm}$ (class 4) and, $<80 \mathrm{~mm}$ (class 5).

To determine the fruit retention rate and June drop, the number of flowers, fruitlets and fruits were recorded during full blossom, fruitlet abscission (a couple of weeks after bloom), the June drop and pre-harvest drop. The observations were made on four randomly selected branches from the four quadrants (north, south, east and west) of every tree.

\section{Fruit Internal Characteristics}

The fruits were cut in half and the thickness of the rind was measured with a Digital Caliper (Mitutoyo CD$15 \mathrm{CPX})$. Using a standard juicer, 25 fruits were weighed and juiced. The juice was weighed and expressed as a percentage of the total fruit weight. The total soluble solids (TSS) content was determined with a portable refractometer (FG-103/113) using a few drops of juice. The total acidity (TA) of the juice was determined by titration with $0.1 \mathrm{~N}$ sodium hydroxide $(\mathrm{NaOH})$ using phenolphthalein as the indicator. The concentration of ascorbic acid was obtained according to the method of Pearson (1970) using a Shimadzu UV-1208 (Shimadzu Scientific Instruments, Japan) spectrophotometer. The method was based on the oxidation of ascorbic acid with 2,6 dichlorophenol indophenol. The reading on the standard curve indicated the ascorbic acid content, and the concentration of ascorbic acid was read at $520 \mathrm{~nm}$.

\section{Statistical Analysis}

The experiment was arranged as ten replicates, respectively, in a 'Complete Randomized Design'. Data were subjected to one-way analysis of variance (ANOVA) using SAS statistical software (SAS v9.0). The percentages recorded in fruit retention and June drop variables were subjected ANOVA after arc-sin transformation. In order to compare treatment means, a Tukey's multiple range test was performed to determine if the differences between treatments were significant at a confidence level of $\mathrm{P}<0.05$.

\section{Results}

Effect on Fruit Yield

A foliar application of 2,4-DP-P had a significant effect on the yield of Star Ruby grapefruit except for trees treated with 50 ppm 2,4-DP-P (Table 1). Treatment 2,4DP-P led to an increase in the yield of fruit, yield to 
canopy volume and TCSA. As shown in Table 1, the highest fruit yield per tree was obtained from trees treated with 300 ppm 2,4-DP-P, followed by 100 and $150 \mathrm{ppm}$ 2,4-DP-P. The lowest fruit yield was obtained from trees treated with $50 \mathrm{ppm}$ 2,4-DP-P and untreated trees. In addition, effects of treatments on yield efficiency $\left(\mathrm{kg} / \mathrm{cm}^{3}\right.$ and $\mathrm{kg} / \mathrm{cm}^{2}$ ) were found to be statistically significant considering canopy volume and trunk cross sectional unit area at a significance level of $\alpha=0.05$ (Table1). Regarding canopy volume and TCSA, the highest fruit yield efficiency was determined in trees treated with $300 \mathrm{ppm}$ 2,4-DP-P, followed by 100 and 150 ppm 2,4-DP-P whereas the lowest yield efficiencies were obtained from the trees treated with $50 \mathrm{ppm}$ and control trees.

The effects of 2,4-DP-P on the fruit retention rate (\%) and June drop (JD) (\%) were statistically significant (Table 2). As shown in Table 2, the lowest june drop rate was obtained from trees treated with 300 ppm 2,4-DP-P, followed by $150 \mathrm{ppm}$ and $100 \mathrm{ppm}$ 2,4-DP-P. The application of 2,4-DP-P led to an increase in the fruit retention rate. Specifically, the application of 300 and 150 ppm 2,4-DP-P resulted in high fruit retention rate. Thus, 2,4-DP-P did not have a thinning effect on the trees, and an increase in the fruit retention rate was observed.

Table 1 The effect of the 2,4-DP-p concentration on the yield and yield efficiency of Star Ruby grapefruit.

\begin{tabular}{l|ccc}
\hline \multirow{2}{*}{ Treatments } & $\begin{array}{c}\text { Fruit yield } \\
(\mathrm{kg} / \text { tree })\end{array}$ & $\mathrm{kg} / \mathrm{m}^{3}$ & Yield efficiency \\
\hline Control & $297.00^{\mathrm{b} 1}$ & $4.987^{\mathrm{b}}$ & $\mathrm{kg} / \mathrm{cm}^{2}$ \\
$50 \mathrm{ppm}$ & $276.00^{\mathrm{b}}$ & $4.634^{\mathrm{b}}$ & $0.569^{\mathrm{b}}$ \\
$100 \mathrm{ppm}$ & $328.50^{\mathrm{ab}}$ & $5.516^{\mathrm{ab}}$ & $0.528^{\mathrm{b}}$ \\
$150 \mathrm{ppm}$ & $313.20^{\mathrm{ab}}$ & $5.259^{\mathrm{ab}}$ & $0.629^{\mathrm{ab}}$ \\
$300 \mathrm{ppm}$ & $365.14^{\mathrm{a}}$ & $6.131^{\mathrm{a}}$ & $0.600^{\mathrm{ab}}$ \\
\hline Prob>F & 0.0140 & 0.0138 & $0.699^{\mathrm{a}}$ \\
\hline
\end{tabular}

${ }^{1}$ Columns of each series (tree yield, yield efficiency) with different letters are significant at a confidence level of 0.05 regarding Tukey's HSD test.

Table 2 The effect of the 2,4-DP-p concentration on june drop (\%) and fruit retention rate (\%) of Star Ruby grapefruit.

\begin{tabular}{l|cc}
\hline Treatments & June drop $(\%)^{1}$ & Fruit retention rate $(\%)$ \\
\hline Control & $96.58(79.40)^{2 \mathrm{a}}$ & $3.42(10.65)^{\mathrm{c}}$ \\
$50 \mathrm{ppm}$ & $96.68(79.54)^{\mathrm{a}}$ & $3.32(10.50)^{\mathrm{c}}$ \\
$100 \mathrm{ppm}$ & $95.13(77.30)^{\mathrm{b}}$ & $4.87(12.75)^{\mathrm{b}}$ \\
$150 \mathrm{ppm}$ & $95.12(77.32)^{\mathrm{b}}$ & $4.88(12.73)^{\mathrm{b}}$ \\
$300 \mathrm{ppm}$ & $94.06(75.97)^{\mathrm{c}}$ & $5.94(14.07)^{\mathrm{a}}$ \\
\hline Pr>F & 0.0074 & 0.0017 \\
\hline
\end{tabular}

${ }^{1}$ Columns with different letters are significant at a confidence level of 0.05 regarding Tukey's HSD test. ${ }^{2}$ Data in parenthesis are arc-sin transformed values.

Table 3 The effect of the 2,4-DP-p concentration on the fruit properties of Star Ruby grapefruit.

\begin{tabular}{|c|c|c|c|c|c|c|c|c|}
\hline Treatments & $\begin{array}{c}\text { Fruit } \\
\text { weight }(\mathrm{g})\end{array}$ & $\begin{array}{l}\text { Fruit diameter } \\
\qquad(\mathrm{mm})\end{array}$ & $\begin{array}{l}\text { Rind thick. } \\
(\mathrm{mm})\end{array}$ & $\begin{array}{c}\text { Juice content } \\
(\%)\end{array}$ & $\begin{array}{l}\text { TSS } \\
(\%)\end{array}$ & $\begin{array}{l}\text { TA } \\
(\%)\end{array}$ & TSS/TA & $\begin{array}{c}\text { Ascorbic acid } \\
(\mathrm{mg} / 100 \mathrm{~g})\end{array}$ \\
\hline Control & $204.39^{\mathrm{ab}}$ & $77.76^{\mathrm{ab}}$ & 5.89 & 40.48 & 12.25 & 2.90 & 4.22 & 61.97 \\
\hline $50 \mathrm{ppm}$ & $216.33^{\mathrm{ab}}$ & $78.98^{\mathrm{ab}}$ & 6.08 & 42.69 & 12.36 & 3.00 & 4.12 & 61.43 \\
\hline $100 \mathrm{ppm}$ & $199.95^{\mathrm{b} 1}$ & $75.88^{b}$ & 5.78 & 44.25 & 11.62 & 3.30 & 3.52 & 59.88 \\
\hline $150 \mathrm{ppm}$ & $237.67^{\mathrm{a}}$ & $82.53^{\mathrm{a}}$ & 6.17 & 41.34 & 12.63 & 3.65 & 3.46 & 60.37 \\
\hline 300 ppm & $210.49^{\mathrm{ab}}$ & $79.99^{\mathrm{ab}}$ & 6.03 & 42.69 & 13.20 & 2.60 & 5.08 & 60.03 \\
\hline $\operatorname{Pr}>F$ & 0.0010 & 0.0013 & ns & ns & ns & ns & $\mathrm{ns}$ & ns \\
\hline
\end{tabular}

${ }^{1}$ Columns with different letters are significant at a confidence level of 0.05 regarding Tukey's HSD test.

Effect on Fruit Weight and Fruit Diameter Distribution at Maturity

In terms of fruit weight, treatments had significant effects on fruit weight at a significance level of $\alpha=0.05$ (Table 3). The highest fruit weight was obtained from trees treated with $150 \mathrm{ppm}$ 2,4-DP-P, followed by 50 ppm, 300 ppm 2,4-DP-P and control trees. The lowest fruit weight was observed in the $100 \mathrm{ppm} 2$,4-DP-P. The results showed that the concentration of $150 \mathrm{ppm} 2,4-\mathrm{DP}$ $\mathrm{P}$ increased fruit weight. Generally, 2,4-DP-P applied to the entire tree increased the fruit diameter of Star Ruby grapefruit except for trees treated with 100 ppm 2,4-DP-P (Table 3). The maximum increase in the diameter of the fruits was obtained from trees treated with $150 \mathrm{ppm}$ 2,4DP-P during physiological drop. According to the results obtained in this study 150 ppm 2,4 DP-P application had positive effects on fruit diameter and fruit size increased.

The application of 2,4-DP-P to the entire tree significantly increased the diameter of Star Ruby grapefruit (Table 3). The maximum increase in the diameter of the fruits was obtained from trees treated with 150 ppm 2,4-DP-P during physiological drop, followed by $300 \mathrm{ppm}$ 2,4-DP-P. The smallest fruit diameter was obtained from the trees treated with 100 ppm 2,4-DP-P.

Fig. 1 shows the effects of 2,4-DP-P treatments on the distribution of the crop within commercial fruit size classes. The results indicated that the frequency distribution of the fruit shifted toward larger sizes when the trees were treated with 2,4-DP-P. The highest percentage of large, commercially valuable Star Ruby 
fruits (> $93 \mathrm{~mm}$ and 89.00-93.00 $\mathrm{mm}$, class 1 and 2 , respectively) was obtained from trees with treated 150 ppm 2,4-DP-P, followed by $300 \mathrm{ppm}$ and $100 \mathrm{ppm} 2,4-$ DP-P. Moreover, compared with the control trees, trees treated with 2,4-DP-P produced a higher percentage of class $3(84.00-89.00 \mathrm{~mm})$. The highest percentage of commercially unacceptable fruits (diameter $<80 \mathrm{~mm}$ ) was obtained from the control trees.

\section{Effects on the Internal Characteristics of Fruit}

Data in Table 3 showed the effect of 2,4- DP-P treatments on fruit internal quality of Star Ruby grapefruit. All treatments did not affect fruit internal quality and significant differences in the rind thickness, juice content, TSS content, acidity (TA), TSS/TA ratio and Ascorbic acid were not observed. There were no trends observed for internal fruit quality due to treatments with 2,4- DP-P.

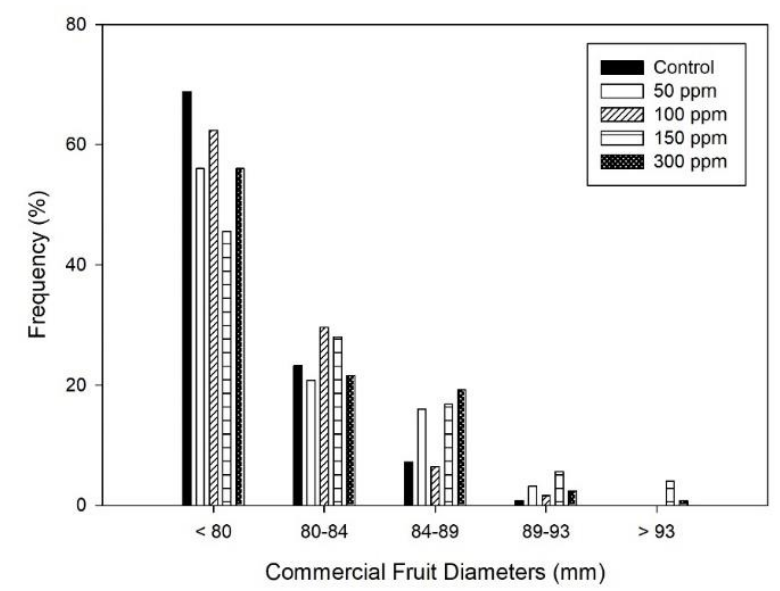

Figure 1 Frequency distribution of the diameter of Star Ruby grapefurit at harvest

\section{Discussion}

The results of the present study indicated that, the application of 2,4-DP-P increased the fruit yield and yield efficiency $\left(\mathrm{kg} / \mathrm{tree}, \mathrm{kg} / \mathrm{m}^{3}\right.$ and $\left.\mathrm{kg} / \mathrm{cm}^{2}\right)$. The time and rate of 2,4-DP-P application had a positive effect on the yield except for trees treated with 50 ppm 2,4-DP-P, and a reduction in fruit yield was not observed. A foliar spraying treatment of 2,4-DP-P at the concentration of $300 \mathrm{ppm}$ resulted the highest fruit yield followed by 100 and $150 \mathrm{ppm}$ 2,4-DP-P. Similar results were obtained by Chao et al. (2004), who studied Fina Sodea clementine mandarins, and found that a post bloom application of 2,4-D (2,4-Dichlorophenoxyacetic acid) significantly increased the yield. In addition to Abd El-Rahman et al. (2011), reported that the application of 50 ppm GA with or without $0.5 \%$ urea increased fruit yield. Similarly, a significant increase in the fruit yield of Star Ruby grapefruit was determined from 150 ppm 2,4-DP (Yesiloglu et al., 2017; Koç, 2012). In addition to Yazıc1 et al. (2016), who studied Star Ruby grapefruit, and reported that 100 and $150 \mathrm{ppm}$ 2,4-DP increased fruit yield. Greenberg et al. (1996), who indicated that 2,4-DP application increased total yield of Valencia orange.
The application of 2,4-DP-P significantly improved the fruit retention rate and june drop. Specifically, trees treated with 2,4-DP-P displayed significantly higher fruit retention rates than the control trees, and thinning effects were not observed. The results obtained in the present study are in concordance with those of Saraswathi et al. (2003), who demonstrated that the highest fruit retention rate was obtained $(28.32 \%)$ from trees treated with 20 ppm 2,4-D. In comparison, the fruit retention rate of the control trees in the aforementioned study was only 20.32\%. Similarly, Yesiloglu et al. (2017) and Koç (2012), who studied Star Ruby grapefruit, reported that 2,4-DP (150 ppm) treatment led to an increase in the fruit retention rate in comparison with the control trees. In another study reported that, 100 and $150 \mathrm{ppm}$ 2,4-DP applications increase the fruit retention of Star Ruby grapefruit (Yazıc1 et al., 2016). In a previous study, the application of 2,4-D (15 mg L_1) delayed the abscission of navel oranges (Stewart and Klotz 1947). Moreover, foliar applications of 2,4-DP significantly reduced abscission in mature Washington navel sweet oranges (Agusti et al., 2006).

The results of the present study indicated that the fruit weight of trees treated with 150 ppm 2,4-DP-P was higher than that of the control. Specifically, an increase in the fruit weight was observed when treatments were applied during natural physiological fruit drop (when the mean fruit diameter was $13-15 \mathrm{~mm}$ ). The results obtained in the present study are in agreement with those described in a previous report by Greenberg et al. (1996), who studied the effects of 2,4-DP on Valencia oranges. Similarly, Yazıcı et al. (2016) and Koç (2012) reported that $150 \mathrm{ppm}$ 2,4-DP-P treatment in Star Ruby grapefruit increased fruit size. Moreover, the results of the present investigation concur with those of Duarte et al. (1996), who studied Esbal clementine mandarins, and found that the average fruit weight of trees treated with 2,4-D was greater than that of the control. Moreover, Modise et al. (2009) verified the results of Duarte et al. (1996) and demonstrated that various concentrations of 2,4-D had a significant effect on fruit weight. Several other auxins such as 3,5,6-TPA, GA3 and chelated zinc/GA 3 have also been reported to increase the weight of fruit (Agusti et al., 1995, 2001; Abd El-Moneim et al., 2007).

Fruit size is a decisive external quality parameter in citrus at the marketing of fresh citrus fruits. Thus, synthetic auxins are commonly used to increase the size of fruit for fresh consumption. In the present study, fruit diameter was significantly affected by the application of 2,4-DP-P. Specifically, treatment with 2,4-DP-P increased the number of large fruits and reduced the number of fruits with a diameter $>80 \mathrm{~mm}$. In previous studies, fruits harvested from trees treated with 2,4-DP were significantly larger than that of the control trees, indicating that the application of 2,4-DP and 2,4-D increased fruit size (El-Otmani et al., 1993; Erner et al., 1993; Agusti et al., 1996; Greenberg et al., 1996; Koch et al., 1996; Gravina et al., 1998; Mesejo et al., 2003; Chao et al., 2004; Erner et al., 2004; Fang et al., 2008; Koç, 2012; Yazic1 et al., 2016). 2,4-DP has given good results in increasing the fruit size of various citrus varieties without any significant thinning effects (Vanniere and Arcuset, 1989; Agusti and Almela, 1991). Similar results 
have also been reported for other auxins. For instance, applications of 10-20 ppm 3,5,6-trichloro-2 pyridiloxyacetic acid (3,5,6-TPA) increased the fruit size of Fino lemons (Garcia-Lido et al., 1992), satsuma mandarins (Agusti et al., 1994) clementine mandarins (Agusti et al., 1995) and Fina Sodea clementine mandarins (Chao and Lovatt, 2010). In addition, Gravina et al. (1998) demonstrated that treatment with 3,5,6-TPA increased the mean fruit size of Ellendale tangor. Moreover, Summers et al. (2008) found that the application of $3,5,6$-TPA $\left(10 \mathrm{mg} \mathrm{L}^{-1}\right)$ to fruit with an average diameter of $24 \mathrm{~mm}$ increased the size of fruit by 6.9-7.4 cm. Similarly, applications of naphthalene acetic acid increased the fruit size of Okitsu mandarin (Rivadeneira et al., 2015), Fino clementine mandarins (Van Rensburg et al., 1996) and Valencia oranges (Greenberg et al., 1996). In addition to Ferrer et al. (2017), reported that an increase in the fruit size of Murcott tangor treated with BA.

The major internal fruit quality, including rind thickness, juice content, total soluble solids, total acid and ascorbic acid, were generally not affected by 2,4-DP-P treatments, as previously observed by other researchers (Davies et al., 1999; Agusti, 2000; Pozo et al., 2000; Saraswathi et al., 2003; Almeida et al., 2008; Yazıcı et al., 2016; Ferrer et al., 2017).

\section{Conclusions}

In this study, we tried to determine how fruit size and yield affected by the usage of auxin treatments. As a conclusion regarding the parameters estimated in this study, treatments had positive effects on fruit yield and size in Star Ruby grapefruit and also 150 ppm 2,4-DP-P treatment had better results than control trees in terms of the commercially valuable fruits. According to the preliminary results obtained from this study, the yield is high and sustainable and due to the increase in fruit size, $150 \mathrm{ppm} 2,4 \mathrm{DP}$ application is recommended for Star Ruby grapefruit.

\section{References}

Abd El-Moneim EAA, Abd El Migeed MMM, Ismail OMM. 2007. GA3 and Zinc sprays for improving yield and fruit quality of Washington navel orange trees grown under sandy soil conditions. Res. J. of Agric. and Biol.Sci. 3 (5): 498503.

Abd El-Rahman GF, Hoda MM, Enshrah AHT. 2011. Effect of GA3 and Potasisum nitrate in different dates on fruit set, yield and splitting of Washington navel orange. Nature and science, 9(12):196-204.

Agusti M, Almela V. 1991. Aplicación de fitorreguladores en citricultura. Ed. AEDOS, SA., Barcelona, Spain.

Agusti M, Almela V, Juan M, Primo-Millo E, Trenor I, Zaragoza S. 1994. Effects of 3,5,6-trichloro-2pyridyloxyacetic acid on fruit size and yield of clausellina mandarin (Citrus unshiu Marc.). Jour. of Hort. Sci. 69 (2): 219-223.

Agusti M, El-Otmani M, Aznar M, Juan M, Almela V. 1995. Effect of 3,5,6-trichloro-2-pyridyloxyacetic acid on Clementine early fruitlet development and on fruit size at maturity. Jour. of Hort. Sci. 70 (6): 955-962.
Agustí M, Almela V, Zaragoza S, Primo-Millo E, El-Otmani M. 1996. Recent finding on the mechanism of action of the synthetic auxins used to improve fruit size of citrus. Proc. Int. Soc. Citriculture 2: 922-928.

Agustí M. 2000. Regulation of citrus cropping and improvement of fruit quality using exogenous plant growth regulators. Proc. Int. Soc. Citriculture 1: 351-356.

Agustí M, Zaragoza S, Iglesias DJ, Almela V, Primo-Millo E, Talón M. 2001. The synthetic auxin 3,5,6-TPA stimulates crbohydrate accumulation and growth in citrus fruit. Plant Growth Regulation. 00:1-7.

Agustí M, Juan M, Martínez-Fuentes A, Mesejo C, Reig C, Almela V. 2006. Application of 2,4dichlorophenoxypropionic acid 2-ethylhexyl ester reduces mature fruit abscission in Citrus navel cultivars. Jour. of Hort. Sci. \& Biotechnology 81 (3): 532-536.

Almeida IML, Ono EO, Rodrigues JD. 2008. Plant growth regulators on the pre-harvest period of Pera oranges. Ciência Rural, 38 (3): 665-671.

AKIB. 2017. http: // www. ntg. org. tr / uploads / 3 /files/ NTG $\% 20$ De \%C4 \%9 Değerlendirme\%20 Raporu\%20Ocak Aral\%C4\%B1k\%202016.pdf (in Turkish).

Chao CT, Lowatt CJ, Ferguson L. 2004. Efficacy of plant growth regulators and fertilizers to increase fruit set and fruit size of Fina Sodea Clementine mandarins in California. Proc. Int. Soc. Citriculture 2: 547.

Chao CT, Lowatt CJ. 2010. Foliar applied 3,5,6-trichloro-2pyridoxylacetic acid (3,5,6-TPA) increases yield of commercially valuable large-size fruit of "Fina Sodea" clementine mandarin. Acta Hort. 884: 433-440.

Davies FS, Campbell CA, Zalman GR, Fidelibus M. 1999. Gibberellic acid application timing effects on juice yield and peel quality of Hamlin oranges. Proc.Fla. State Hort. Soc. 112: $22-24$.

Duarte AMM, Trindada DTG, Guardiola JL. 1996. Thinning of Esbal Clementine with 2,4-dichlorophenoxypropionic acid.Influence on yield, fruit size and fruit quality. Proc. Int. Soc. Citriculture 2: 929-933.

El-Otmani M, Agustí M, Aznar M, Almela V. 1993. Improving the size of Fortune mandarin fruits by auxin 2,4-DP. Scient. Hortic. 55 (3-4): 283-290.

El-Otmani M, Coggins CW Jr, Agustí M, Lovatt C. 2000. Plant growth regulators in citriculture: World current uses. Critical Reviews in Plant sciences. 19: 395-447.

Erner Y, Tagari E, Hamou M, Katzir I. 2004. Enhancing citrus fruit size: An overview of opportunities and achievements in Israel. Proc. Int. Soc. Citriculture 2: 495-501.

Fang JG, Wu CJ, Zheng YS, Chao CT. 2008. Application of 2,4$\mathrm{D}$ for fruit size and yield increase of W. Murcott mandarin and Minneola tangelo in California. 11th Int. Citrus Congress. 26-30 October 2008, China. Abs. No: 158. p 81-82.

Gallasch PT. 1988. Chemical thinning of heavy crops of mandarins to increase fruit size. Proc. 6th Int. Citrus Congress 1: 395-405.

Garcia-Lidon A, Porras-Castillo I, Ortíz Marcide J, Molina R. 1992. Early harvesting of Fino lemon using a new synthetic auxin. Proc. Int. Soc. Citriculture 1: 473-474.

Goldschmidt EE, Koch KE. 1996. Citrus. In: Zamski E and Schafer AA (eds), Photoassimilate distribution in plants and crops. Source-sink relationships. Marcel Dekker, Inc., NewYork, pp.797-823.

Gravina A, Arbiza H, Bozzo A, Laserre E, Arias M, Ronca F. 1998. Synthetic auxins evaluation on fruit size and yield in Ellendale tangor. Acta Hortic. 463:413-418.

Greenberg J, Eshel G, Gotfreed A. 1996. Effects NAA, 2,4-D and 2,4-DP on yield, fruit size and creasing of Valencia orange. Proc. Int. Soc. Citriculture 2: 934-937.

Guardiola JL, Almela V, Barres MT. 1988. Dual effect of auxins on fruit growth in Satsuma mandarin. Scient. Hortic.34: 229-237. 
Guardiola JL. 1997. Increasing citrus fruit size with synthetic auxins. In: Futch SH and Kender WJ (eds) Citrus Flowering and Fruiting Short Course. Univ.of Florida. pp 79-86.

Guardiola JL, García-Luis A. 2000. Increasing fruit size in Citrus. Thinning and stimulation of fruit growth. Plant growth regulation 31:121-132.

Koch N, Theron K, Rabe E. 1996. Fruit seize prediction in Clementine and Satsuma mandarin and improvement of Clementine mandarin (Citrus reticulata Blanco) fruit size by 2,4-DP. Proc. Int. Soc. Citriculture 2: 737-744.

Koç S. 2012. Kimyasal seyreltme, bilezik alma, budama ve potasyum uygulamalarının Star Ruby altıntop çeşidinde meyve iriliği üzerine etkileri. Yüksek Lisans Tezi, Çukurova Üniversitesi Fen Bilimleri Enstitüsü. $81 \mathrm{~s}$, Adana.

Laskowski L, Monnerri C, Garcia-Luis A, Guardiola JL. 2008. Vascularizacion del pedicole y crecimiento del fruto de Citrus sinensis var. Salustiana y su relaction con el contenido de acido indolacetico. Biagro 20(1): 11-20.

Mesejo C, Martínez-Fuentes A, Juan M, Almela V, Agustí M. 2003. Vascular tissues development of citrus fruits peduncle is promoted by synthetic auxins. Plant Growth Regulation, 39, 131-135.

Modise DM, Likuku AS, Thuma M, Phuti R. 2009. The influence of exogenously applied 2,4-dichlorophenoxyacetic acid on fruit drop and quality of navel oranges (Citrus sinensis L.). African J. of Biotechnology. 8 (10): 2131-2137.

Pearson D. 1970. The Chemical Analyses of Foods. Pp. 233. In: J and A. Churchill (eds.), 104 Glucuster Place, London.

Pozo L, Kender WJ, Burns JK, Hartmond U. 2000. Effects of Gibberellic acid on ripening and rind puffing in Sunburst mandarin. Proc.Fla. State Hort. Soc. 113:102-105.

Rivadeneria MF, Gomez C, Muller WS. 2015. Fruit thinning of Satsuma "Okitsu" mandarin. Acta Hort. 10.17660/ActaHortic.2015.1065.156.

Saraswathi T, Rangasamy P, Azhakiamanavalan RS. 2003. Effect of preharvest spray of growth regulators on fruit retention and quality of mandarins. South Ind. Hort. 51 (1/6): 110-112.

SAS. 2009. SAS/STAT User's Guide, Ver. 9. SAS Institute Inc., Cary, N.C.

Stewart WS, Hoed HZ, Brannamann BL. 1952. Effects of 2,4-D and related substances on fruit drop, yield, size and quality of Valencia orange. Hilgardia 21:321-329.
Summers L, Weng A, Zheng YS, Lowatt CJ. 2008. Effects of the Diphenylurea Cytokinin CPPU and the Auxin 3,5,6-TPA on Washington navel orange yield, fruit size and quality. 11th Int. Citrus Congress. 26-30 October 2008, China. Abs. No: $157 . p$ 80-81.

TUIK. 2017. Turkish Statistic Council records (Ankara: TUIK), www.tuik.gov.tr.

Turrel FM. 1946. Tables of surfaces and volumes of spheres and of prolate and oblate spheroids and spheroidal coefficients. University of California, Press. Berkeley.

Vanniere H, Arcuset P. 1989. Amelioration du calibres des clementines en Corse par l'emploi du dichlorprop. Fruits 44: 393-400.

Van Rensburg P, Shung-Shi P, García-Luis A, Fornés F, Guardiola JL. 1996. Improving crop value in Fino clementine mandarin with plant growth regulators. Proc. Int. Soc. Citriculture 2: 970-974.

Wheaton TA. 1981. Fruit thinning of Florida mandarins using plant growth regulators. Proc. Int. Soc. Citriculture 1: 263268.

Yazıc1 K, Biner B, Eryılmaz Z. 2016. 2,4diklorofenoksipropiyonik asit (2,4-DP) uygulamalarının Star Ruby altıntop (Citrus paradise Macf.) çeşidinde verim ve meyve kalitesi üzerine etkileri. Mediterranean Agricultural Sciences. 29(2): 39-42.

Yesiloglu T, Koc S, Cimen B. 2017. The usage of auxins with various cultural techniques to increase fruit size in Star Ruby grapefruit. Fresenius Environmental Bulletin, 26 (10): 5717-5722.

Yildirim B, Yesiloglu T, Incesu M, Kamiloglu M, Ozguven F, Tuzcu O, Aka Kacar Y. 2010. The effects of mechanical pruning on fruit yield and quality in 'Star Ruby' grapefruit. Journal of Food, Agriculture \& En-vironment. 8(2): 834838.

Yildirim B, Yesiloglu T, Incesu M, Kamiloglu M, Cimen B, Tamer S. 2012. Effects of 2,4-DP (2,4dichlorophenoxypropionic acid) plant growth regulator on fruit size and yield of Valencia oranges (Citrus sinensis Osb.). New Zealand Journal of Crop and Horticultural Science, 40(1): 55-64. 